\title{
Job Crafting dan Kebosanan Kerja Karyawan
}

\section{Employee's Job Crafting and Job Boredom}

\author{
Faraz Umaya ${ }^{1}$, Rizki Maulina ${ }^{2}$, Sus Budiharto ${ }^{3}$ \\ Fakultas Psikologi dan Ilmu Sosial Budaya, Universitas Islam Indonesia

\begin{abstract}
The purpose of this study was to determine the relationship between the effect of job crafting training and a decrease in the level of job boredom. The hypothesis proposed: there are differences in the level of job boredom of the experimental-control group. The research design used a pretest-posttest control group design. The concept of job boredom was measured using the Dutch Boredom Scale (DUBS) test kit adapted from Reijseger, et.al. Measurement of job crafting using the Job Crafting Scale (JCS) was adapted from Tims, et.al. Data analysis using the Mann Whitney U. Analysis results stated that the value of $Z=-2.067$ and $p=0.039(p<0.05)$. The results showed that there was a difference in the level of job boredom between the experimental group that was given training and the control group that was not given training. This means that job crafting training is an important alternative in overcoming job boredom.
\end{abstract}

Keywords: employees; job boredom; job crafting; training

Abstrak. Tujuan penelitian ini ingin mengetahui hubungan pengaruh antara pelatihan job crafting dan penurunan tingkat kebosanan kerja. Hipotesis yang diajukan adalah terdapat perbedaan tingkat kebosanan kerja kelompok eksperimen-kontrol. Rancangan penelitian menggunakan desain kelompok kontrol prates-pascates. Konsep kebosanan kerja diukur menggunakan alat tes Dutch Boredom Scale (DUBS) diadaptasi dari Reijseger, et al. Pengukuran job crafting menggunakan Job Crafting Scale (JCS) diadaptasi dari Tims, et.al. Analisis data menggunakan Mann Whitney $U$. Hasil analisis menyebutkan nilai $Z=-2,067$ dan $p=0,039(p<0,05)$. Hasil ini menunjukkan adanya perbedaan skor secara signifikan tingkat kebosanan kerja kelompok eksperimen dan kontrol, setelah diberi pelatihan. Artinya, pelatihan job crafting merupakan alternatif penting dalam mengatasi kebosanan kerja.

Kata Kunci: job crafting; karyawan; kebosanan kerja; pelatihan

Kebosanan di tempat kerja adalah sebuah keniscayaan di mana setiap karyawan setidaknya pernah mengalami kebosanan di semua tingkat pekerjaan. Namun feno-

Korespondensi mengenai artikel ini dapat dilakukan melalui159151301@uii.ac.id mena kebosanan di tempat kerja kurang mendapatkan perhatian, baik dari para pemilik perusahaan maupun dunia akademik (Pekrun, et al. 2010). Konsep kebosanan belum banyak dikaji (Bench \& Lench, 2013). Alasan yang diberikan para ahli antara lain, pertama karena tidak adanya definisi konsep kebosanan yang 
kuat, jelas, serta logis. Kebosanan dipandang sebagai karakteristik individu yang melekat, sebagai perasaan sementara atau sebagai motif. Kebosanan juga mirip dengan emosi dan keadaan mental lainnya seperti kelelahan, mengantuk, dan depresi. Buku Handbook of Emotions, karya HavilandJones, dan Feldman Barrett, tidak membahas masalah "boredom" kecuali pernyataan bahwa "boredom" bisa diatasi atau diredusi dengan semangat bergembira dan menumbuhkan rasa keingintahuan (Pekrun, et al., 2010).

Kebosanan di tempat kerja berhubungan dengan rasa kantuk, ketidakmampuan untuk berkonsentrasi pada tugas, tidak suka atau jengkel pada tugas, tidak mampu memusatkan perhatian, membutuhkan waktu yang lama untuk memperhatikan dan memperbaiki kesalahan, dan memiliki risiko kecelakaan yang lebih besar (Game, 2007). Kebosanan kerja berimplikasi pada rendahnya kinerja, rendahnya kepuasan kerja, kebiasaan bolos, intensitas turnover, cuti dini, kesehatan diri yang kurang baik, dan perilaku kerja kontradiktif, dan kerugian kerja (Bruursema, Kessler \& Spector, 2011; Reijseger, Schaufeli, Peeters, Taris, Beek, \& Ouweneel, 2013; Harju, Hakanen, Schaufeli, 2014).

Dari perspektif psikologi organisasi, kebosanan kerja sering didefinisikan sebagai komponen keadaan dan sifat. Keadaan, maksudnya, kebosanan mengacu pada kejadian yang bersifat lebih sementara yang dipengaruhi lingkungan, sedangkan komponen sifat mengacu pada karakteristik yang lebih stabil yang melekat pada diri seseorang. Dengan demikian, kebosanan kerja merupakan keadaan motivasional di tempat kerja yang berkaitan dengan karakteristik pekerjaan dan lingkungan kerja itu sendiri (Harju et al., 2014).

Strategi yang ada selama ini untuk mengatasi kebosanan kerja, antara lain mendengar musik di lingkungan tempat kerja (van der Swaluw, 2014), melakukan manajeman waktu secara efektif dan kemampuan proaktif (van der Heijden, Schepers, \& Nijssen, 2012), menciptakan hubungan sosial yang lebih luas serta mencari stimulasi tambahan berupa aktivitas yang disenangi (Loukidou, LoanClarke, \& Daniel, 2009), aktivitas melamun (daydreaming) juga dapat memunculkan pemecahan masalah yang lebih kreatif (Smith, 1981; Mann \& Cadman, 2014).

Metode lain yang dilakukan para peneliti, menguji beberapa intervensi untuk menurunkan kebosanan di lingkungan kerja seperti pelatihan kebermaknaan kerja (Anas, 2017), pelatihan motivasi kerja (Kurniawati, 2014), redesain peralatan kerja (Susihono \& Kulsum, 2015), musik penggiring (Riyadi, As'ad, \& Nurmawati, 2002). Beberapa penelitian tersebut menurut peneliti mempunyai beberapa kelemahan. Pelatihan kebermaknaan kerja untuk menurunkan kebosanan melaporkan adanya kelemahan, di mana hasilnya menunjukkan inkonsistensi perubahan kebosanan kerja antara prates-pascates dan pascates-tindak lanjut (Anas, 2017). Pelatihan motivasi kerja, juga tidak memberikan efek positif untuk jangka panjang (Kurniawati, 2014). Pemberian intervensi musik di lingkungan kerja dianggap kurang tepat, karena banyak bukti musik justru membuat bising (Riyadi, et al., 2002). Semua ini menunjukkan bahwa dibutuhkan variasi intervensi lain yang 
perlu dilakukan untuk menurunkan kebosanan atau kejenuhan bekerja karyawan.

Banyak faktor penyebab kejenuhan kerja, antara lain pekerjaan itu sendiri, lingkungan kerja, dan kesesuaian antara diri dan pekerjaan (Fisher, 1993). Menurut Fisher (1987), karakteristik pekerjaan merupakan faktor yang memainkan peran penting terkait kebosanan kerja. Karyawan yang dapat mengubah karakteristik pekerjaannya dengan cara-cara yang proaktif dalam membentuk atau menyusun pekerjaannya untuk memenuhi kebutuhan, keterampilan dan motivasi individu, terbukti dapat mengubah kebosanan (Wrzesniewski dan Dutton, (2001). Perilaku proaktif ini disebut dengan job crafting, yakni aktivitas yang dilakukan karyawan untuk membentuk tugas, lingkungan atau pola pikirnya agar tercipta kondisi kerja yang lebih berarti bagi dirinya sendiri (van Hooff \& van Hooft, 2014).

Penelitian job crafting yang dilakukan van Hooff dan van Hooft (2014) menunjukkan bahwa job crafting berhubungan negatif terhadap kebosanan kerja. Harju, Hakanen, dan Schaufeli (2016) menyebutkan bahwa mencari tantangan baru di tempat kerja dapat meningkatkan keterlibatan karyawan, mencegah kebosanan kerja dan menghasilkan perilaku job crafting lainnya. Penelitian ini memilih konsep job crafting sebagai strategi intervensi alternatif untuk mengatasi masalah kebosanan kerja, yang relatif jarang diteliti di Indonesia.

Studi ini merujuk dimensi job crafting yang dikembangkan Tims, Bakker, dan Derks (2012), khususnya untuk penyusunan modul, yang terdiri dari empat dimensi yaitu increasing structural job resources, increasing social resources, increasing challenging job demands, decreasing hindering job demands. Namun, studi ini tidak melibatkan dimensi decreasing hindering job demands, karena dimensi tersebut diakui kurang efektif dalam menurunkan tingkat kejenuhan kerja.

Penelitian ini bertujuan mengetahui pengaruh pelatihan job crafting terhadap kebosanan kerja. Pelatihan merupakan intrumen intervensi yang biasa digunakan para peneliti dalam rangka meningkatkan efektivitas pemberdayaan terutama dimensi human resource (Cummings \& Worley, 2015). Pelatihan ini dirancang berdasarkan konsep experiental learning yang dapat mengubah struktur kognitif, sikap serta ketrampilan yang dimiliki peserta (Johnsen \& Johnsen, 2009). Experiental learning terdiri dari experience (proses mengalami), publishing (berbagi), processing (analisa pengalaman), generalizing (menarik kesimpulan), applying (menerapkan). Hipotesis penelitian ini adalah terdapat hubungan pengaruh antara pelatihan job crafting terhadap penurunan kebosanan kerja karyawan.

\section{Metode}

Penelitian ini menggunakan variabel Kebosanan kerja (Y) dan Job Crafting (X). Definisi kebosanan kerja merujuk konsep Reijseger, et.al.. (2013), yaitu perasaan yang tidak menyenangkan dan tidak memuaskan yang dirasakan individu selama melakukan pekerjaan yang ditandai dengan perasaan gelisah, kelesuan, ketidakmampuan untuk berkonsentrasi, merasa waktu berjalan dengan lambat serta cenderung melakukan 
aktivitas yang tidak berhubungan dengan pekerjaan. Job Crafting diartikan sebagai upaya terencana, melalui pelatihan, yang dilakukan organisasi untuk membantu karyawan dalam menambahkan pengetahuan, keterampilan dan tingkah laku untuk membuat pekerjaan menjadi lebih menarik, menyenangkan, dan bermakna bagi dirinya.

\section{Subjek penelitian}

Karyawan Toko Buku di Yogyakarta yang bekerja sebagai pramuniaga, menjadi subjek penelitian ini, dengan karakteristik telah bekerja minimal enam bulan, dan mempunyai level kebosanan kerja sedang dan tinggi. Jumlah subjek sebanyak 20 orang, masing-masing 10 untuk kelompok eksperimen dan kontrol.

\section{Desain penelitian}

Rancangan penelitian ini adalah pre-test post-test control group design. Rancangan ini mengukur sebelum dan sesudah perlakuan diberikan (Latipun, 2008). Prates dan pascates dilakukan untuk mengontrol konstansi terhadap proactive history (Seniati, Yulianto, \& Setiadi, 2011).

\section{Instrumen penelitian}

Data dikumpulkan melalui skala kebosanan kerja yakni Dutch Boredom Scale (DUBS) yang disusun Reijseger, et al., (2013). Alat ukur DUBS ini terdiri dari enam aitem, di mana seluruh aitem merupakan favorable. Untuk penskalaan menggunakan model summated rating method, di mana subjek memilih jawaban yang sesuai dengan keadaan subjek. Pilihan jawaban terdiri dari, tidak pernah diberi skor (0), hampir tidak pernah diberi skor (1), jarang diberi skor (2), kadang-kadang diberi skor (3), sering diberi skor (4), sangat sering diberi skor (5), selalu diberi skor (6).

Modul pelatihan job crafting merujuk pada konsep Tims, et al. (2012), yang terdiri dari lima bagian yaitu, pembukaan, increasing structural job resources, increasing social job resources, challenging job demands, dan penutup. Sementara, pelaksanaan pelatihannya, mengacu pada modul pelatihan yang disusun peneliti.

\section{Prosedur intervensi}

Pelaksanaan pelatihan job crafting dilakukan selama satu hari. Pengungkapan aspek job crafting dilakukan dalam lima sesi, dan menggunakan waktu selama tujuh jam atau 430 menit, sejak pagi hingga sore hari. Pelatihan job crafting dirancang dengan menggunakan metode teknik simulasi dan lecture, serta strategi pembelajaran yang memberikan pengalaman langsung kepada para peserta pelatihan atau disebut experiental learning (Ancok, 2007). Kemudian pada akhir pelatihan dilakukan evaluasi pelatihan untuk mengetahui pencapaian tujuan pelatihan.

Pengukuran dilakukan sebanyak tiga kali. Prates dilakukan di awal penelitian untuk variabel kebosanan kerja dan job crafting terhadap.... Setelah diberikan pelatihan job crafting pada kelompok eksperimen, selanjutnya dilakukan pengukuran pascates dengan alat yang sama. Sepuluh hari setelah pengukuran pascates, peneliti melakukan pengukuran tingkat lanjut kepada subjek penelitian.

\section{Teknik analisis data}

Untuk menganalisis data, penelitian ini menggunakan Mann Whitney U Test, yakni 
alat uji yang digunakan untuk mengetahui perbedaan dua kelompok data, di mana satu sama lain tidak saling berhubungan. Teknik ini termasuk statistik nonparametrik, digunakan karena distribusi data tidak normal atau jumlah subjek sangat sedikit.

\section{Hasil}

Analisis yang dilakukan untuk uji beda kelompok eksperimen dan kontrol menyebutkan nilai $Z=-1,253$ dan skor $p=$ 0,210 , sehingga $p>0,005$. Hasil analisis tersebut menyatakan tidak ada perbedaan yang signifikan mengenai kebosanan kerja kelompok eksperimen-kontrol sebelum diberikan pelatihan (prates) job crafting (lihat Tabel 1 dan Gambar 1).

Analisis skor pascates menyebutkan nilai $Z$ sebesar $-2,067$ dan tingkat signifikansi sebesar 0,039 $(p<0,05)$. Artinya, terdapat perbedaan skor secara signifikan antara kelompok eksperimen dan kontrol. Dapat juga dikatakan bahwa ditemukan perbedaan pada variabel kebosanan kerja antara kelompok eksperimen dan kontrol setelah diberikan pelatihan job crafting, dengan demikian hipotesis diterima (lihat Tabel 1 dan Gambar 2)

Sumbangan efektif (effect size) dari pelatihan yang diberikan terhadap penurunan tingkat kebosanan kerja diperoleh nilai sebesar 0,462 atau 46,2\%. Berarti pelatihan job crafting memiliki kekuatan sebesar $46.2 \%$ dalam menurunkan kebosanan kerja pada karyawan pada kelompok eksperimen. Berikut perhitungan sumbangan efektif:

$$
\begin{gathered}
r(\text { effect size })=\frac{Z}{\sqrt{N}}=\frac{-2.067}{\sqrt{20}}=0.462 \\
\text { Effect size }=0.462 \times 100 \%=46.2 \%
\end{gathered}
$$

Keterangan:

$\mathrm{Z}=$ Statistik Hitung

$\mathrm{N}=$ Total Jumlah Subjek

Analisis tindak lanjut (follow up) kelompok eksperimen-kontrol menyebutkan nilai $Z$ sebesar -1.712 dan taraf signifikansinya sebesar $0,087(p>0,05)$. Artinya, tidak terdapat perbedaan skor signifikan pada saat pengukuran tindak lanjut, yaitu 10 hari setelah pelatihan diberikan (lihat Tabel 1 dan Gambar 3).

\section{Diskusi}

Studi ini bertujuan mengetahui pola hubungan pengaruh yakni pemberian pelatihan job crafting terhadap upaya menurunkan tingkat kebosanan kerja pada kelompok karyawan yang bekerja di Toko Buku. Analisis data tentang pelatihan job crafting itu menunjukkan bahwa hipotesis penelitian diterima. Hasil analisis ini dapat dilihat dari skor nilai signifikansi pada

Tabel 1.

Hasil Analisis Mann Whitney U Test Kebosanan Kerja

\begin{tabular}{cccc}
\hline Tipe Tes & Nilai Z & Sig. & Keterangan \\
\hline Prates & $-1,253$ & 0,210 & Tidak Signifikan \\
Pascates & $-2,067$ & 0,039 & Signifikan \\
Tindak Lanjut & $-1,712$ & 0,087 & Tidak Signifikan \\
\hline
\end{tabular}




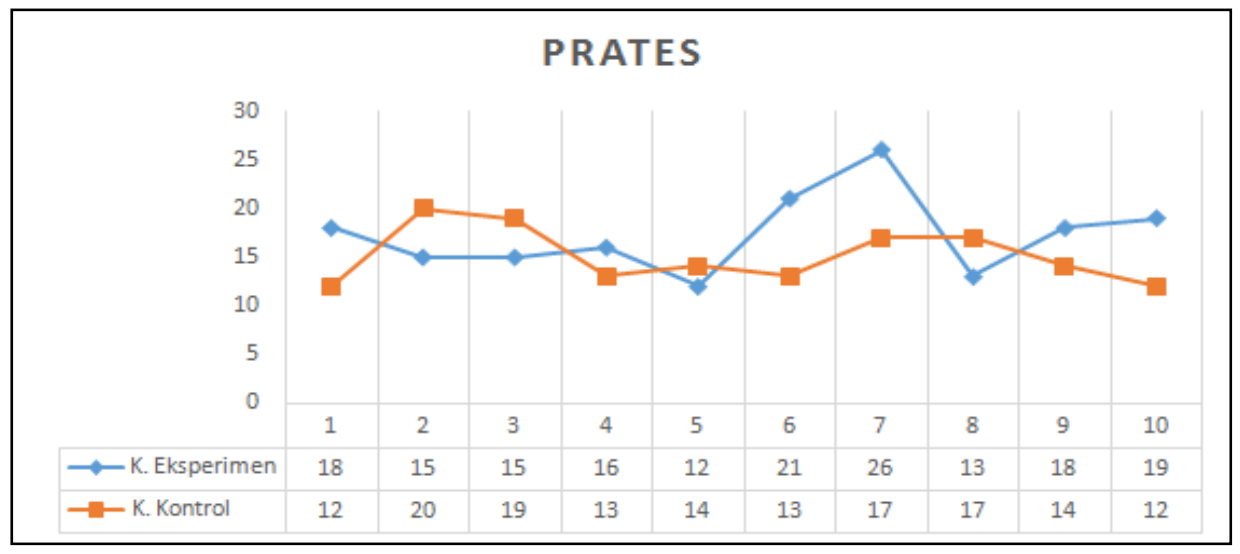

Gambar 1. Grafik skor prates

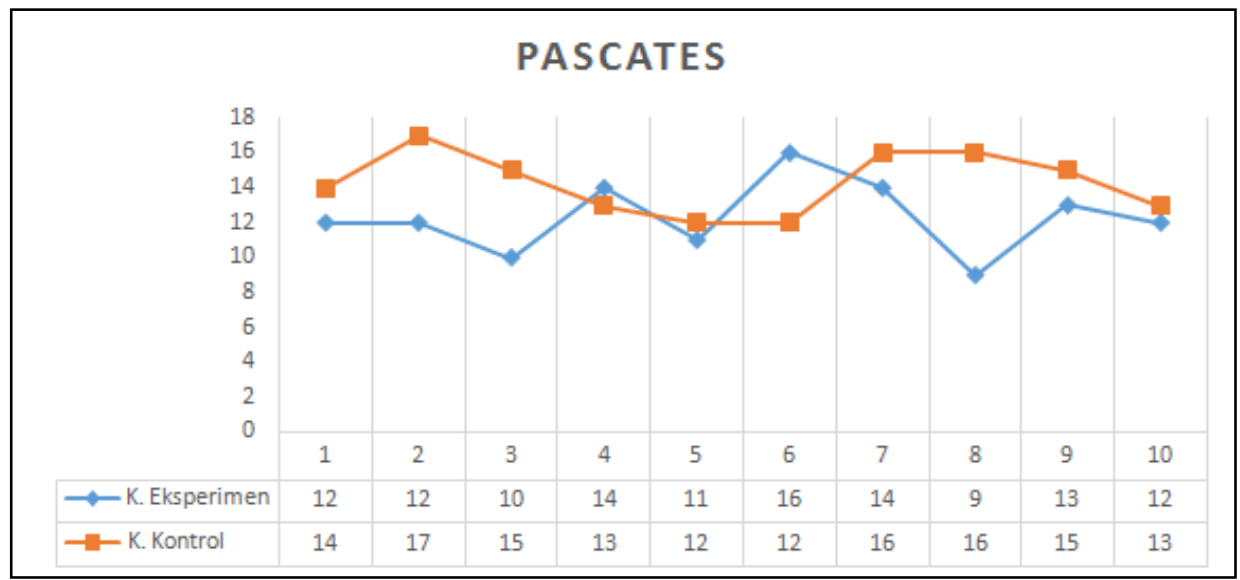

Gambar 2. Grafik skor pascates

pascates sebesar $p=0,039$ dengan $p<0,05$, maka dapat dikatakan ada perbedaan signifikan antara kelompok eksperimen dan kontrol, di mana subjek pada kelompok eksperimen mengalami penurunan kebosanan kerja, dibandingkan kelompok kontrol. Sumbangan efektif (effect size) dari pelatihan yang diberikan diperoleh sebesar 0,462 atau $46,2 \%$, dengan kata lain, pelatihan job crafting memiliki kekuatan sebesar 46,2\% dalam menurunkan kebosanan kerja.
Kesimpulan studi ini kurang lebih sama dengan studi-studi sebelumnya, antara lain dengan hasil studi van Hooff dan van Hooft (2014) tentang "boredom at work". Penelitian Harju et al., (2016) yang menguji apakah perilaku job crafting dapat memprediksi rendahnya kebosanan kerja, juga menemukan hal yang sama bahwa tantangan kerja dapat meningkatkan keterlibatan kerja karyawan dan menurunkan kebosanan kerja. 


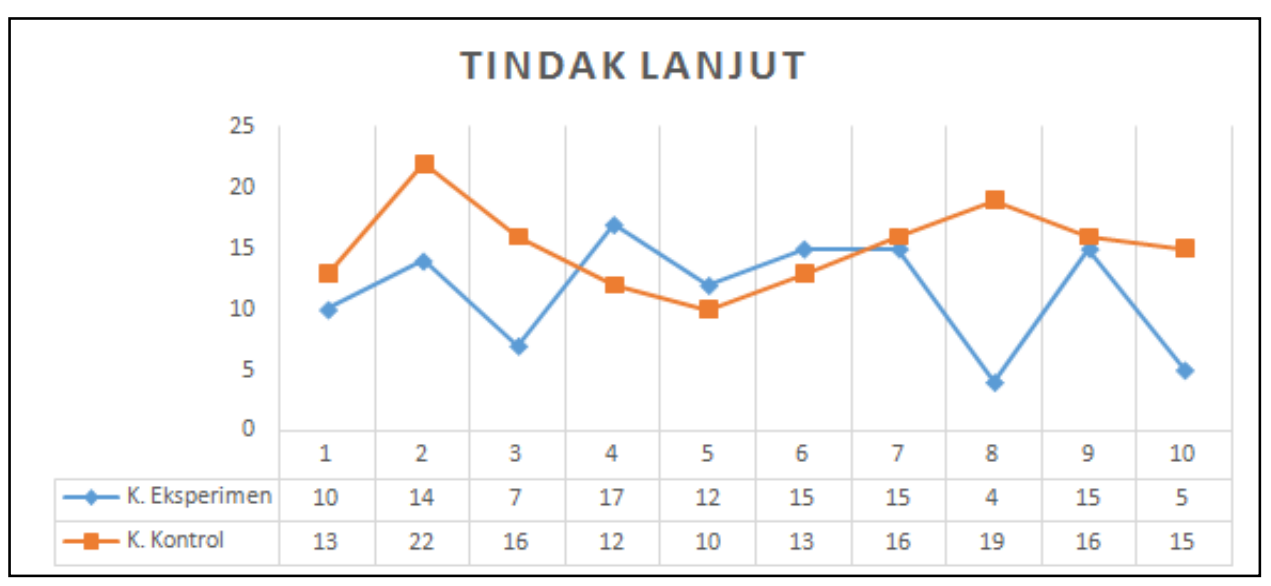

Gambar 3. Grafik skor tindak lanjut

Dalam mengkaji job crafting, Tims, et al. (2012) menggunakan paradigma job demand-resources, di mana karyawan bersikap proaktif menyeimbangkan antara tuntutan pekerjaan dan sumber daya pekerjaan dengan kemampuan dan kebutuhannya. Hal ini sesuai juga dengan penelitian Reijseger, et al. (2013) yang menerapkan model job demand-resources juga terhadap kebosanan kerja. Hasil penelitiannya menyatakan bahwa tuntutan pekerjaan dan sumber daya pekerjaan berhubungan secara negatif terhadap kebosanan kerja.

Pelatihan job crafting memfasilitasi karyawan untuk menemukan makna terlebih dahulu dari pekerjaan yang dilakukannya. Pada sesi pertama karyawan diperlihatkan tayangan yang bertujuan untuk mengevaluasi kembali tujuan bekerja. Melalui sesi ini, karyawan mampu memaknai pekerjaan dari sudut pandang yang luas, yaitu bekerja bukan hanya untuk mendapatkan materi, status sosial maupun kebutuhan ekonomi semata. Karyawan diberi pemahaman bahwa bekerja sebagai wujud ibadah kepada Tuhan.

Pada sesi kedua "increasing challenging job demands", pelatihan job crafting membantu karyawan untuk memahami pentingnya tantangan dalam bekerja. Pada awal sesi ini, peserta diajak untuk bermain permainan "borgol", dari permainan ini peserta terlihat antusias dan terus mencoba untuk menyelesaikan permaianan yang diberikan meskipun dirasa cukup sulit. Menurut Fitri (2013) salah satu kriteria yang dapat digunakan sebagai acuan job crafting, apakah pekerjaan yang diberikan itu memiliki tantangan (tingkat kesulitan) atau tidak. Pada sesi ini karyawan diminta menyadari kesulitan dalam diri, dan diminta untuk merefleksikan masalah yang pernah dihadapi, baik dengan rekan kerja maupun pelanggan. Tugas ini membantu karyawan untuk menyadari bahwa tantangan itu dapat muncul baik dari dalam maupun dari luar dirinya. Pada sesi kedua ini juga, karyawan diajak mengidentifikasi masalah yang dihadapi, yang pada dasarnya dapat menjadi tantangan dalam bekerja.

Sesi ketiga pelatihan yaitu "increasing structural job resources". Pada sesi ini, karyawan didorong untuk mampu mempelajari hal baru dari pekerjaannya. Melalui aktivitas identifikasi hal yang menyenangkan, menantang dan 
membosankan, diharapkan karyawan dapat mempelajari hal baru dari apa yang disampaikan rekannya. Pada sesi ini karyawan saling berbagi pekerjaan yang telah ditulis tersebut menjadi hal yang menyenangkan, menantang dan membosankan. Kemudian karyawan diminta untuk menyusun "my activity" berisikan jadwal harian yang akan dikerjakan karyawan. Penugasan ini membuat karyawan memiliki otonomi untuk membuat pekerjaan menjadi menarik sesuai dengan karakter dirinya masingmasing. Harju (2017) mengatakan individu yang memiliki kemampuan dan otonomi untuk melakukan perubahan dalam pekerjannya dapat memacu aktivitas job crafting, sebaliknya karakteristik kerja yang menghambat otonomi karyawan maka dapat menghambat job crafting.

Pada sesi keempat "increasing social job resources", karyawan bermain permainan "tangan terkait". Dari permainan ini terlihat seluruh karyawan berusaha untuk menyelesaikan permainan yang diberikan. Setelah menyelesaikan permainan, fasilitator menanyakan hal apa yang membuat karyawan mampu menyelesaikan permainan tersebut, beberapa karyawan menjawab karena adanya dukungan dari rekan lainnya untuk tetap semangat menyelesaikan permainan. Faktor dukungan sosial dari rekan kerja dapat mendorong dan memotivasi karyawan lain untuk menyelesaikan pekerjaannya meskipun dirasa terlalu berat (Iswanto dan Agustina, 2016). Pada sesi ini karyawan juga diajak melakukan role play dengan cara berpasangan untuk saling berbagi (sharing) terkait dengan permasalahan yang sering muncul di tempat kerja.

Menarik untuk dibahas di sini, mengapa pada pengujian tindak lanjut hasilnya menunjukan bahwa tidak ada perbedaan antara kelompok eksperimen dan kontrol. Banyak faktor yang berpotensi sebagai penyebab, seperti tingkat kebosanan yang dialami subjek, dukungan organisasi yang diberikan kepada subjek, kemampuan subjek dalam menyerap materi selama proses pelatihan berlangsung, dan kesungguhan pada setiap subjek dalam menjalankan proses pelatihan.

Hal ini sesuai dengan hasil pengamatan selama pelatihan berlangsung, di mana karyawan belum mengaplikasikan apa yang telah didapatkan dari pelatihan. Ketika pelatihan berlangsung, karyawan diajak untuk melakukan role play terkait dengan seni menyusun buku. Harapannya dengan melakukan hal tersebut, karyawan menjadi lebih tertantang untuk menemukan variasi-variasi baru dalam menyusun buku-buku dagangan. Berdasarkan wawancara singkat, karyawan mengaku belum termotivasi untuk menyusun buku dagangan secara menarik karena belum ada karyawan lainnya yang memberi contoh. Sedangkan menurut Dutton, Roberts dan Bednar (2010) hal mendasari karyawan melakukan aktivitas job crafting adalah adanya inisiatif atau keinginan mendasar dalam diri karyawan untuk membuat pekerjaannya menjadi lebih menarik dan berarti. Karyawan yang secara proaktif mampu menciptakan pekerjaan yang lebih berarti dapat mencegah terjadinya kebosanan di tempat kerja (Harju, et al., 2016). 
Berdasarkan observasi juga, terlihat bahwa peserta tidak antusias dan merasa seperti terbebani ketika fasilitator membagikan lembar rencana aksi yang harus dikerjakan peserta. Kondisi ini berdampak pada hasil tugas rencana aksi, di mana banyak karyawan yang tidak mengerjakan tugas tersebut dengan baik. Ketika peneliti bertanya mengapa tidak mengerjakan dengan baik, ada karyawan yang mengaku dirinya masih malas untuk menerapkan apa yang telah didapatkan. Keterbatasan penelitiaan ini, terutama terjadi karena subjek yang relatif sedikit sehingga berpengaruh pada effect size yang tidak terlalu besar. Pelaksanaan pascates yang dilaksanakan secara langsung juga kurang mencerminkan aspek perilaku dari job crafting, dalam penelitian ini hanya diukur dari simulasi.

\section{Kesimpulan}

Kesimpulan penelitian ini menyebutkan bahwa ada hubungan pengaruh antara pelatihan job crafting terhadap pengurangan tingkat kebosanan karyawan di tempat kerja. Artinya memberikan kesempatan pada karyawan untuk berkreasi terhadap pekerjaannya sangat baik dan kondusif bagi karyawan. Kemudian, memberikan feedback kepada karyawan mempunyai nilai besar dalam mencegah karyawan dari perasaan bosan. Terakhir, memberikan pekerjaan yang berbeda atau yang menantang juga akan sangat berguna bagi karyawan dalam mengatasi masalah kebosanan kerja.

Mengacu hasil penelitian, bahwa pelatihan job crafting terbukti berpengaruh untuk meningkatkan daya kreatif karyawan, kemandirian karyawan dan mengurangi tingkat kebosanan karyawan, sehingga kami merekomendasikan kepada para pemilik usaha atau para manajer, seyogyanya dapat memberikan pelatihan job crafting di tempat kerja.

\section{Saran}

Untuk pengembangan penelitian, ada baiknya bagi peneliti selanjutnya untuk mengkaji kebosanan kerja dari sisi positif. Kebosanan kerja dapat memberi dampak positif bagi individu, yakni merangsang individu untuk menghasilkan fantasi dan membangkitkan kreativitas. Ketika individu merasa bosan, muncul keinginan mencari tantangan baru dan memberikan energi untuk melakukan perubahan atau variasi baru. Hal ini dimungkinkan karena individu yang merasa bosan, akan mengalami pergeseran perhatian yang disebut dengan melamun (daydreaming). Kondisi melamun ini memberikan kemampuan individu untuk mengevaluasi dan menguji kembali informasi yang didapatkan dan dengan melamun dapat memunculkan pemecahan masalah yang lebih kreatif (Mann \& Cadman, 2014).

\section{Daftar Pustaka}

Anas, R. (2017). Pengaruh pelatihan kebermaknaan kerja dalam menurunkan tingkat kebosanan kerja karyawan PT X Makassar (Tesis tidak dipublikasikan). Universitas Islam Indonesia, Yogyakarta.

Ancok, D. (2007). Outbound management training. Yogyakarta: UII Press.

Bench, S. W. \& Lench, H. C. (2013). On the function of boredom. Behavioral 
Sciences, 3(3), 459-472. doi: https://doi.org/10.3390/bs3030459

Bruursema, K., Kessler, S. R., \& Spector, P. E. (2011). Bored employees misbehaving: The relationship between boredom and counterproductive work behaviour. Work \& Stress, 25(2), 93-107. doi: https://doi.org/10.1080/02678373.201 1.596670

Cummings, T. G. \& Worley, C. G. (2015). Organization and development change (Edisi kesepuluh). Boston, MA: Cengage Learning.

Dutton, J. E., Roberts, L. M., \& Bednar, J. (2010). Pathways for positive identity construction at work: Four types of positive identity and the building of social resources. Academy of Management Review, 35(2), 265-293. doi: https://doi.org/10.5465/amr.35.2.zok $\underline{265}$

Fisher, C. D. (1987). Boredom: Construct, causes, and consequences. Human Resource Research. Texas A\&M University dan Virginia Polytechnic Institute. Diakses melalui http://www.dtic.mil/dtic/tr/fulltext/ u2/a182937.pdf

Fisher, C. D. (1993). Boredom at work: A neglected concept. Human Relations, 46(3), 395-417. doi: http://dx.doi.org/10.1177/0018726793 $\underline{04600305}$

Fitri, K. (2013). Pengaruh jenjang karir dan tantangan pekerjaan terhadap minat freshgraduate FKIP Universitas Riau pada profesi sales. Jurnal Sosial Ekonomi Pembangunan, 10, 119-135.

Game, A. M. (2007). Workplace boredom coping: Health, safety and HR implications. Personnel Review, 36(5), 701-721.

doi: http://dx.doi.org/10.1108/0048348071 $\underline{0774007}$

Harju, L. K., Hakanen, J. J., \& Schaufeli, W. B. (2014). Job boredom and its correlation in 87 Finnish organizations. Journal of Occupational and Environmental medicine, 56(9), 911-918.

doi:

\section{http://dx.doi.org/10.1097/JOM.00000} $\underline{00000000248}$

Harju, L. K., Hakanen, J. J., \& Schaufeli, W. B. (2016). Can job crafting reduce job boredom and increase work engagement? A three-year crosslagged panel study. Journal of Vacational Behaviour, 95-96, 11-20. doi:

https://doi.org/10.1016/j.jvb.2016.07. $\underline{001}$

Harju, L. (2017). Taming the beast of boredomexploring boredom at work and the role of job crafting (Disertasi tidak dipublikasikan), Aalto University, Leuven. Diakses melalui http://urn.fi/URN:ISBN:978-952-607507-5

Iswanto, F. \& Agustina, I. (2016). Peran dukungan sosial di tempat kerja terhadap keterikatan kerja karyawan. MEDIAPSI, 2(2), 38-45. doi:

http://dx.doi.org/10.21776/ub.mps.20 $\underline{16.002 .02 .6}$

Johnsen, D. W., \& Johnsen, F. P. (2009). Joining together: Group theory and group skill (Edisi ketujuh). Boston, MA: Allyn \& Bacon.

Kurniawati, I. S. (2014). Efektivitas E-JOURNAL GAMAJPP 
pelatihan motivasi kerja untuk menurunkan kebosanan kerja karyawan bagian kasir Assalaam Hypermarket Solo (Tesis tidak dipublikasikan). Universitas Muhammadiyah Surakarta, Solo.

Latipun (2008). Psikologi eksperimen (Edisi kedua). Malang: UMM Pres.

Loukidou, L., Loan-Clarke, J., \& Daniel, K. (2009). Boredom in the workplace: More than monotonous tasks. International Journal of Management Reviews, 11(4), 381-405. doi; https://doi.org/10.1111/j.14682370.2009.00267.x

Mann, S. \& Cadman, R. (2014). Does being bored make us more creative? Creativity Research Journal, 26, 165173. doi: https://doi.org/10.1080/10400419.201 $\underline{4.901073}$

Pekrun, R., Goetz, T., Daniels, L. M., Stupnisky, R. H., \& Perry, R. P. (2010). Boredom in achievement settings: Exploring control-value antecedents and performance outcomes of a neglected emotion. Journal of Educational Psychology, 102(3), 531-549. https://doi.org/10.1037/a0019243

Reijseger, G., Schaufeli, W. B., Peeters, MCW., Taris, T. W., Beek, I., \& Ouweneel, E. (2013). Watching the paint dry at work: Psychometric examination of the Dutch Boredome Scale. Anxiety, Stress, \& Coping, 26, 508-525.

doi: https://doi.org/10.1080/10615806.201 2.720676

Riyadi, S., As'ad, M., \& Nurmawati. R. (2002). Pengaruh musik terhadap kebosanan kerja dan kelelahan kerja di Tunas Asri Keramik Yogyakarta. Sain Kesehatan, 15(3), 283-293.

Seniati, L., Yulianto, A., \& Setiadi, B. N. (2011). Psikologi eksperimen. Jakarta: PT. Indeks.

Smith, R. P. (1981). Boredom: A review. Human Factors: The Journal of the Human Factors and Ergonomics Society, 23(3), 329-340. doi: https://doi.org/10.1177/001872088102 300308

Susihono, W. \& Kulsum. (2015). Partisipatori ergonomi: Redesain hand tools pertanian menurunkan kebosanan kerja. Journal Industrial Services, 1(1), 1-4.

Tims, M., Bakker, A. B., \& Derks, D. (2012). Development and validation of the job crafting scale. Journal of Vacational Behavior, 80(1), 173-186. doi:

https://doi.org/10.1016/j.jvb.2011.05. $\underline{009}$

Van der Heijden, G. A. H., Schepers, J. J. L., \& Nijssen, E. J. (2012). Understanding workplace boredom among white collar employees: Temporary reactions and individual differences. European Journal of Work and Organizational Psychology, 21, 349-375.

doi: https://doi.org/10.1080/1359432X.201 $\underline{1.578824}$

Van der Swaluw, K. (2014). Listening to the past when the present is boring: Nostalgic music as a meaning-regulator (Tesis tidak dipublikasikan). Master Psychology, Utrecht University, Utrecht.

Van Hooff, M. L. M., \& van Hooff, E. A. J. 
UMAYA et al.

(2014). Boredom at work: Proximal and distal consequences of affective work-related boredom. Journal of Occupational Health Psychology, 19(3), 348-359. doi: https://doi.org/10.1037/a0036821

Wrzesniewski, A., \& Dutton, J. E. (2001). Crafting a job: Revisioning employees as active crafters of their work. Academy of Management Review, 26(2), 179-201. doi: https://doi.org/10.5465/amr.2001.4378011 